\title{
PENERAPAN MODEL PEMBELAJARAN KOOPERATIF TIPE MURDER UNTUK MENINGKATKAN HASIL BELAJAR SISWA PADA MATERI BARISAN DAN DERET ARITMATIKA
}

\author{
Pratama $^{1)}$, Muh. Rizal ${ }^{2)}$, Linawati ${ }^{3)}$ \\ pratamarahmat46@gmail.com ${ }^{1)}$,rizaltberu97@yahoo.com ${ }^{2)}$,linawatilugiyanto@gmail.com ${ }^{3)}$
}

\begin{abstract}
Abstrak: Penelitian ini bertujuan untuk memperoleh deskripsi penerapan model pembelajaran kooperatif tipe MURDER untuk meningkatkan hasil belajar siswa pada materi barisan dan deret aritmatika di kelas X TKJ A SMK Negeri 1 Poso Pesisir Utara. Subjek penelitian ini adalah siswa kelas X TKJ A yang berjumlah 20 siswa, terbagi atas 8 siswa laki-laki dan 12 siswa perempua serta di pilih 3 siswa sebagai informan. Penelitian ini adalah Penelitian Tindakan Kelas (PTK) yang mengacu pada desain penelitian Kemmis dan Mc. Taggart yakni (1) perencanaan, (2) pelaksanaan tindakan, (3) observasi, dan (4) refleksi. Penelitian ini dilaksanakan dalam dua siklus. Pada siklus I banyaknya siswa yang tuntas yakni 14 siswa dengan persentase ketuntasan $70 \%$ dan pada siklus II banyak siswa yang tuntas yakni 17 siswa dengan persentase ketuntasan $85 \%$. Hasil observasi aktivitas guru pada siklus I berada pada kategori baik dan mengalami peningkatan pada siklus II berada pada kategori sangat baik. Hasil observasi aktivitas siswa pada siklus I berada pada kategori baik dan mengalami peningkatan pada siklus II berada pada kategori sangat baik. Penerapan model pembelajaran kooperatif tipe MURDER yang dapat meningkatkan hasil belajar siswa kelas X TKJ A SMK Negeri 1 Poso Pesisir Utara pada materi barisan dan deret aritmatika, dengan enam komponen yaitu: 1) Mood, 2) Understand, 3) Recall, 4) Detect, 5) Expand, 6) Review.
\end{abstract}

Kata Kunci: Kooperatif Tipe MURDER; Hasil Belajar; Barisan dan Deret Aritmatika

\begin{abstract}
This study aims to obtain a description of the application of the MURDER type cooperative learning model to improve student learning outcomes in arithmetic sequence and sequence material in class X TKJ A of SMK Negeri 1 Poso North Coast. The subjects of this study were students of class X TKJ A, amounting to 20 students, divided into 8 male students and 12 female students and 3 students were selected as informants. This research is Classroom Action Research (CAR) which refers to the research design of Kemmis and Mc. Taggart namely (1) planning, (2) implementation of actions, (3) observation, and (4) reflection. This research was conducted in two cycles. In the first cycle the number of students who completed were 14 students with a percentage of completeness of $70 \%$ and in the second cycle many students were completed ie 17 students with a percentage of completeness $85 \%$. The results of the observation of teacher activities in the first cycle were in the good category and experienced an increase in the second cycle in the very good category. The results of the observation of student activities in the first cycle were in the good category and experienced an increase in the second cycle in the very good category. The application of the MURDER type cooperative learning model that can improve the learning outcomes of class X TKJ A students of SMK Negeri 1 Poso Pesisir Utara in arithmetic sequence and series material, with six components, namely: 1) Mood, 2) Understand, 3) Recall, 4) Detect, 5) Expand, 6) Review.
\end{abstract}

Keywords: Cooperative Type MURDER; Learning outcomes; Arithmetic Rows and Series.

Matematika merupakan ilmu yang mendasari perkembangan teknologi modern, mempunyai peran penting dalam disiplin ilmu untuk mengembangkan daya fikir manusia. Pada umumnya tidak ada satupun disiplin ilmu yang perkembangannya terlepas dari penggunaan matematika, paling kurang perhitungan matematika tingkat rendah yaitu penjumlahan, perkalian, pembagian, dan pengurangan. Matematika membekali peserta didik untuk mempunyai kemampuan berfikir logis, analitis, sistematis, kritis serta 
kemampuan bekerja sama. Oleh sebab itu, pelajaran matematika perlu diberikan kepada semua peserta didik untuk semua jenjang pendidikan.

Pembelajaran kurikulum 2013 mendasarkan pada konsep bahwa pembelajaran merupakan suatu proses pengembangan potensi dan pembangunan karakter setiap peserta didik sebagai hasil dari sinergi antara pendidikan yang berlangsung di sekolah, keluarga dan masyarakat. Proses Pembelajaran Kurikulum 2013 tersebut memberikan kesempatan kepada peserta didik untuk mengembangkan dan meningkatkan potensi mereka dalam sikap (spiritual dan sosial), pengetahuan, dan keterampilan yangn diperlukan dirinya untuk hidup bermasyarakat, berbangsa, serta berkontribusi pada kesejahteraan hidup umat manusia (Permendikbud No. 104 tahun 2014 tentang Pembelajaran)

Tujuan pembelajaran matematika akan tercapai di lihat tingkat keberhasilan siswa melalui minat siswa dalam belajar dan dalam mengerjakan soal yang diberikan oleh guru dengan mencapai hasil belajar yang baik. Hasil belajar matematika yang diharapkan adalah hasil belajar yang mencapai ketuntasan belajar matematika. Peserta didik dikatakan tuntas dalam belajar matematika apabila peserta didik telah memenuhi kriteria ketuntasan minimum (KKM) yang telah ditetapkan sekolah (Permendiknas No. 20 tahun 2007). Kenyataannya, masih terdapat peserta didik yang belum mampu mencapai tujuan pembelajaran matematika tersebut sehingga diperlukan solusi untuk mengatasi masalah yang muncul di dunia pendidikan.

Berdasarkan hasil wawancara pada tanggal 22 Januari 2019 dengan guru matematika di kelas X TKJ SMK Negeri 1 Poso Pesisir Utara (PPU), guru menyatakan bahwa masih sulit dalam menanamkan konsep materi pelajaran matematika pada materi progam linear, barisan dan deret aritmatika, serta barisan dan deret geometri. Akibatnya hasil pembelajaran siswa pada materi tersebut tergolong belum mencapai target kriteria ketuntasan minimal (KKM) yang telah ditentukan disekolah. Diantara tiga materi yang diungkapkan oleh guru matematika, materi yang paling penting untuk ditangani adalah materi barisan dan deret aritmatika karena pada materi ini banyak siswa yang belum mampu menyelesaikan soal barisan dan deret aritmatika yang diberikan oleh guru. Materi ini juga merupakan materi prasyarat untuk masuk ke materi barisan dan deret geometri dan merupaka pelajaran yang erat kaitannya dengan kehidupan sehari - hari serta merupakan pelajaran yang sering keluar saat ujian nasional.

Informasi selanjutnya bahwa kondisi siswa saat ini hampir sama dengan kondisi siswa pada tahun sebelumnya. Hal ini diperkuat dengan hasil pengamatan peneliti di kelas $X$ TKJ A, dari hasil pengamatan diperoleh informasi bahwa hanya siswa yang berkemampuan tinggi yang aktif dalam proses pembelajaran di kelas dan kurangnya minat belajar siswa saat guru sedang menjelaskan sehingga siswa cenderung sulit dalam memahami konsep pelajaran. Selain itu, siswa malu dalam bertanya serta mudah lupa terhadap materi yang baru saja dipelajari.

Berbagai upaya telah dilakukan guru dalam mengatasi masalah tersebut, diantaranya dengan menerapkan metode diskusi dengan harapan siswa dapat memahami konsep materi barisan dan deret aritmatika dengan baik namun hasilnya hanya siswa yang berkemampuan tinggi yang aktif dalam pembelajaran di kelas, siswa cenderung mudah lupa terhadap materi yang baru saja guru terangkan serta kurangnya minat belajar siswa saat guru sedang menjelaskan sehingga siswa sulit memahami konsep materi barisan dan deret aritmatika yang diajarkan oleh guru. Selain itu guru juga telah menerapkan metode tanya jawab dengan tujuan memberi kesempatan kepada siswa untuk berani bertanya mengenai materi 
yang guru jelaskan, namun hasilnya sebagian besar siswa masih takut dalam bertanya tentang materi yang belum mereka pahami.

Mengatasi masalah tersebut maka peneliti berkolaborasi dengan guru kelas X TKJ A mulai dari perencanaan hingga pelaksanaan tindakan pembelajaran dengan menerapkan suatu model pembelajaran yang sesuai terhadap masalah yang guru alami serta sesuai dengan karakteristik siswa dalam pembelajaran di kelas sehingga diharapkan bisa meningkatkan hasil belajar siswa pada materi barisan dan deret aritmatika. Model pembelajaran yang ditawarkan adalah model pembelajaran koopertif tipe MURDER (Mood, Understand, Recall, Detect, Expand, Review) yang diperkenalkan oleh Hythecker, Danserau, dan Rocklin pada tahun 1988 (Jacob et al, 1997;santyasa, 2006).

Fase-fase model pembelajaran tipe MURDER diharapkan dapat mengatasi masalah yang guru alami dalam mengajar di sekolah. Dalam Fase mood (suasana hati), diharapkan dapat memotivasi siswa untuk belajar karena pada fase ini siswa diberikan informasi berupa fenomena-fenomena menarik yang berkaitan dengan materi pelajaran yang akan dipelajari dan dihubungkan dengan kehidupan sehari-hari sehingga siswa akan lebih antusias dalam menerima pembelajaran. Fase understand (pemahaman), diharapkan dapat mengatasi siswa yang kurang pemahamannya karena pada fase ini siswa dilibatkan langsung dalam mengkonstruksi pemahamannya sendiri. Fase recall (pengulangan), diharapkan dapat mengatasi siswa yang mudah lupa, karena dalam fase ini siswa di arahkan untuk menuliskan informasi yang telah di terima dengan pemahaman serta kata-kata mereka sendiri dan mengulang kembali pembelajaran dengan berdiskusi bersama teman di dalam kelompoknya. Fase Detect (menemukan), dilakukan dengan memanfaatkan sumber belajar lain dalam menyelesaikan suatu permasalahan sehingga membuat siswa aktif dalam mencari jawaban dan menemukan kesalahan-kesalahan saat mengerjakan tugas dengan teman diskusinya. Fase expand (pengembangan), dilakukan dengan menugasi siswa untuk menyelesaikan suatu masalah dan mengaitkannya dengan kehidupan sehari-hari. Fase review (menyimpulkan), dilakukan dengan menyimpulkan materinya.

Santayasa (2006) menyatakan bahwa kelebihan dari pembelajaran kooperatif tipe MURDER adalah dapat memperkuat pemahaman karena siswa di latih untuk mengemukakan, menjelaskan, memperluas, dan mencatat ide-ide utama dari materi secara verbal. Dalam hal ini, keterampilan memperoleh informasi lebih diutamakan karena memungkinkan siswa untuk menghubungkan informasi-informasi yang cukup penting dengan pengetahuan atau pengalaman yang dimiliki sebelumnya.

Berdasarkan uraian tersebut peneliti melakukan suatu penelitian tentang penerapan model pembelajaran kooperatif tipe MURDER untuk meningkatkan hasil belajar siswa pada materi barisan dan deret aritmatika di kelas X TKJ A SMK Negeri 1 PPU.

\section{METODE PENELITIAN}

Pendekatan yang digunakan dalam penelitian ini adalah pendekatan kualitatif, karena pelaksanaan penelitian ini lebih mengarah pada peningkatan kualitas pembelajaran yang diinginkan. Jenis penelitian ini adalah penelitian tindakan kelas (PTK). Desain penelitian ini mengacu pada model Kemmis dan Mc. Tanggart (Arikunto dalam Yuniarti, 2017) yang terdiri atas empat komponen, yaitu perencanaan, pelaksanaan tindakan, observasi dan refleksi. Subjek penelitian ini adalah seluruh siswa kelas siswa kelas X TKJ SMK Negeri 1 Poso Pesisir Utara yang terdaftar pada tahun ajaran 2019/2020 yang terdiri dari 20 siswa terbagi atas 8 siswa laki-laki dan 12 siswa perempuan. Pemilihan subjek penelitian berdasarkan saran dari guru bidang studi matematika kelas X TKJ A. 
Teknik pengumpulan data pada penelitian ini adalah dengan cara observasi, wawancara, catatan lapangan, dan tes analisis data yang dilakukan dengan mengacu pada analisis data kualitatif pada model Miles dan Huberman antara lain, reduksi data, penyajian data dan kesimpulan. Keberhasilan tindakan yang dilakukan di lihat dari tindakan aktivitas guru dalam mengelola pembelajaran di kelas dan tindakan aktivitas siswa selama mengikuti pembelajaran dengan menggunakan model pembelajaran kooperatif tipe MURDER.

Kategori keberhasilan tindakan pada siklus I dan siklus II dikatakan berhasil, apabila: (1) siswa dapat menentuksan suku ke-n suatu barisan dan deret aritmatika, (2) siswa dapat mengerjakan soal barisan dan deret aritmatika secara kontekstual, jika hasil belajar siswa memperoleh Standar Kriteria Minimal (SKM) minimal 75\%. Kategori keberhasilan tindakan pada data kualitatif yaitu nilai rata-rata (NR) aktivitas guru dan siswa minimal berada dalam kategori baik atau $70 \%<\mathrm{N}_{\mathrm{R}} \leq 85 \%$ untuk setiap siklus.

\section{HASIL PENELITIAN}

Tahap pra tindakan, peneliti memberikan tes awal kepada siswa untuk mengetahui kemampuan awal siswa pada materi prasyarat. Banyaknya siswa yang mengikuti tes awal adalah 20 siswa yang terdaftar di kelas X TKJ A SMK Negeri 1 Poso Pesisir Utara. Hasil tes awal kemudian di analisis oleh peneliti, menunjukkan sebagian siswa belum mampu menyelesaikan soal dengan benar. Umumnya sebagian siswa belum dapat mengurutkan pola bilangan pada suku ke-n dan lupa terhadap rumus barisan dan deret aritmatika, hal ini terlihat dengan hanya 1 orang dari 20 siswa yang dapat menjawab dengan benar dan mendapat nilai 100, sehingga memberi gambaran bahwa hasil belajar siswa terhadap materi prasyarat masih sangat rendah.

Pelaksanaan kegiatan pembelajaran dilakukan oleh guru dalam tiga tahap yaitu kegiatan pendahuluan, kegiatan inti dan kegiatan penutup. Adapun fase-fase model pembelajaran koopratif tipe MURDER terdiri dari enam langkah pembelajaran, yaitu: (1) fase mood (menumbuhkan minat belajar siswa), (2) fase understand (pembentukan pemahaman) (3) fase recall (mengulang ide utama) (4) fase detect (menemukan kekeiruan), (5) fase expand (memperluas), (6) fase review (menyimpulkan materi).

Guru matematika kelas X TKJ A melakukan kegiatan pembelajaran berpedoman pada rencana pelaksanaan pembelajaran (RPP) yang menerapkan model pembelajaran kooperatif tipe MURDER. Pelaksanaan tindakan pada siklus 1 dilaksanakan sebanyak 2 kali pertemuan. Pada pertemuan pertama dilaksanakan penyajian materi barisan dan deret aritmatika. Kegiatan tersebut berlangsung pada hari jum'at, tanggal 22 Maret 2019 di kelas $\mathrm{X}$ TKJ A SMK Negeri 1 Poso Pesisir Utara mulai pukul 7.45 sampai dengan 09.15 WITA (2 x 45 menit)

Observasi dilakukan dengan mengamati aktivitas guru dan siswa selama pembelajaran berlangsung. Observasi terhadap aktivitas siswa dilakukan oleh Gayuh dan Jumiati. Sedangkan lembar observasi terhadap aktivitas guru matematika (Marnika Bella S.Pd) kelas X TKJ SMK Negeri 1 Poso Pesisir Utara dilakukan oleh peneliti sendiri (Rahmat Pratama). Berikut dijelaskan hasil kegiatan pembelajaran yang dilaksanakan guru matematika kelas X TKJ A dan hasil observasi aktivitas guru dan siswa selama pelaksanaan tindakan pembelajaran mengacu pada fase-fase model pembelajaran kooperatif tipe MURDER sebagai berikut :

Kegiatan awal yang dilakukan guru saat memulai pembelajaran yaitu mempersiapkan siswa untuk belajar di awali dengan mengucapkan salam pembuka dan berdoa bersama sesuai dengan keyakinan masing-masing. 
Selanjutnya guru mengecek kehadiran siswa dan mengarahkan siswa untuk berkonsentrasi dalam pembelajaran. Guru menyuruh siswa untuk menyimpan perlengkapan yang tidak ada kaitannya dengan pembelajaran sehingga tidak akan mengganggu proses pembelajaran dan juga meminta siswa untuk menyiapkan buku dan alat tulis yang akan digunakan.

Guru menyampaikan subpokok bahasan yang akan dipelajari dan guru juga menyampaikan tujuan pembelajaran yang hendak di capai setalah siswa mempelajari materi tersebut. Guru menyampaikan materi prasyarat kemudian memberikan beberapa pertanyaan kepada siswa terkait materi prasyarat yang di kenal dengan pemberian apersepsi. Terlihat siswa sangat antusias dengan arahan dan himbauaan dari guru.

Berdasarkan hasil analisis data aktivitas guru dan siswa dalam proses pembelajaran dengan penerapan model MURDER pada fase mood diperoleh informasi bahwa guru menjelaskan materi yang akan dipelajari dan memotivasi siswa agar siswa merasa rileks dan semangat dalam belajar namun guru tidak mengaitkan manfaat barisan dan deret aritmatika dengan kehidupan sehari-hari misalnya mengetahui hasil produksi barang yang berjalaan secara konstan melalui rumus barisan aritmatika, banyaknya jumlah tabungan siswa yang terkumpul selama satu tahun melalui rumus deret aritmatika, dan mengetahui urutan siswa saat melakukan baris berbaris di lapangan upacara. Sehingga diperoleh skor 3 atau berketegori baik.

Kesimpulan dari lima kelompok pada aspek mood yakni terdapat dua kelompok berkategori kurang dengan skor 2 dan tiga kelompok berkategori baik dengan skor 3 . Hal ini dapat disimpulkan bahwa pada aspek mood rata-rata memperoleh skor 3 atau ketegori baik dengan gambaran bahwa siswa menyimak penjelasan dari guru mengenai materi yang akan dipelajari dan menyimak manfaat barisan dan deret aritmatika namun siswa tidak mengaitkannya dengan kehidupan sehari-hari.

Berdasarkan hasil analisis data aktivitas guru dan siswa dalam proses pembelajaran dengan penerapan model MURDER pada fase understand diperoleh informasi bahwa guru melakukan pembentukan pemahaman kepada siswa dengan meminta siswa mencermati materi pada LKPD tetapi guru tidak mengarahkan siswa untuk mencatat poin-poin penting yang ada dalam materi sehingga sebagian siswa dalam kelompok masih mudah lupa terhadap materi pada LKPD yang telah guru berikan dan skor yang diperoleh pada fase ini adalah 3 atau berkategori baik.

Kesimpulan dari lima kelompok pada aspek understand yakni rata-rata memperoleh skor 3 atau berketegori baik dengan gambaran bahwa siswa menerima LKPD yang dibagikan oleh guru serta mencermati materi pada LKPD tetapi siswa tidak mencatat poinpoin penting dalam materi.

Berdasarkan hasil analisis data aktivitas guru dan siswa dalam proses pembelajaran dengan penerapan model MURDER pada fase recall diperoleh informasi bahwa guru mengarahkan siswa untuk mengulang ide utama pada LKPD dengan cara membaca, memahami, dan mendiskusikan tugas-tugas yang terdapat pada LKPD sehingga ingatan siswa tentang materi makin tertanam dengan baik, akan tetapi masih banyak siswa yang malu dalam menyampaikan pendapatnya karena guru tidak meminta salah satu anggota dyad untuk mengungkapkan pemahamannya kepada pasangan kelompoknya dan skor diperoleh adalah 3 atau berkategori baik.

Kesimpulan dari lima kelompok pada aspek recall yakni rata-rata memperoleh skor 3 atau berkategori baik dengan gambaran siswa membaca, memahami, dan mendiskusikan tugas-tugas yang terdapat pada LKPD namun setelah itu siswa tidak mengungkapkan pemahamannya terhadap LKPD kepada pasangannya. 
Berdasarkan hasil analisis data aktivitas guru dan siswa dalam proses pembelajaran dengan penerapan model MURDER pada fase detext diperoleh informasi bahwa guru mengarahkan siswa dalam anggota dyad yang lainnya untuk mendengarkan sambil mendeteksi adanya kesalahan dalam penjelasan pasangannya serta guru mengarahkan masing-masing dyad-1 dan dyad-2 untuk saling memperlihatkan hasil pekerjaan siswa sehingg terlihat siswa mulai aktiv dalam belajar dan berdiskusi bersama teman kelompoknya. Akan tetapi guru tidak menyuruh siswa membandingkan dan mendiskusikan LKPD terhadap pasangannya sehingga ada sebagian siswa yang masih malu dalam mengungkapkan pemahamannya kepada pasangannya dan skor yang diperoleh pada fase ini adalah 3 atau berkategori baik sesuai dengan rubric penilaiaan aktivitas guru.

Kesimpulan dari lima kelompok pada aspek detect yakni rata-rata memperoleh skor 3 atau berkategori baik dengan gambaran bahwa siswa mendengarkan sambil mendeteksi adanya kesalahan atau kekeliruan dalam penjelasan pasangannya tetapi masing-masing dyad-1 dan dyad-2 tidak saling memperlihatkan hasil pekerjaan, kemudian siswa tidak membandingkan dan mendiskusikannya.

Berdasarkan hasil analisis data aktivitas guru dan siswa dalam proses pembelajaran dengan penerapan model MURDER pada fase expand diperoleh informasi bahwa guru mengarahkan pasangan dyad untuk menanggapi dan memberikan sanggahan terkait pernyataan yang muncul pada tahap detect, terlihat sebagian siswa sudah berani mengungkapkan pemahamannya dalam memberikan contoh materi yang dipelajari tetapi siswa tidak mengaitkannya dengan kehidupan sehari-hari sehingga skor yang diperoleh adalah 3 atau berkategori baik.

Kesimpulan dari lima kelompok pada aspek expand yakni rata-rata memperoleh skor 2 atau berkategori kurang dengan gambaran bahwa siswa menanggapi dan memberikan sanggahan terkait pernyataan yang muncul pada tahap detect tetapi siswa tidak memberikan contoh materi yang dipelajari dan siswa tidak mengaitkannya dengan kehidupan sehari-hari.

Berdasarkan hasil analisis data aktivitas guru dan siswa dalam proses pembelajaran dengan penerapan model MURDER pada fase review diperoleh informasi bahwa guru membimbing setiap kelompok untuk menyimpulkan materi pelajaran dan melakukan revisi terhadap LKPD namun guru tidak menyuruh siswa untuk mengumpulkan LKPD sehingga diperoleh skor 3 atau berkategori baik.

Kesimpulan dari lima kelompok di aspek review sebagian besar memperoleh skor 4 atau berkategori sangat baik dengan gambaran bahwa siswa menyimpulkan dan melakukan revisi terhadap LKPD yang akan siswa kumpulkan.

Penelitian ini dilakukan dengan memberikan tes akhir tindakan pada setiap siklusnya. Tes akhir tindakan pada siklus I dilaksanakan pada hari sabtu 23 Maret 2019 mulai pukul 09.15 sampai 10.00 dengan alokasi waktu 1 x 45 menit. Terdapat 4 butir soal dalam tes akhir tindakan siklus I. Berdasarkan hasil analisis tes akhir tindakan siklus I, diperoleh informasi bahwa jumlah siswa yang tuntas adalah 14 dari 20 siswa yang mengikuti tes, dengan nilai persentase ketuntasan belajar klasikal sebesar $70 \%$.

Berdasarkan hasil wawancara peneliti dengan ketiga informan pada siklus I diperoleh informasi bahwa:

"Informan 1 (MS) sebenarnya sudah mampu menyelesaikan semua soal dengan benar misalnya pada nomor 1 , namun pada soal nomor 4 mengenai deret aritmatika, MS mengatakan sudah kehabisan waktu dalam mengerjakannya sehingga MS hanya menuliskan hal yang diketahui." Berikut jawaban MS untuk soal nomor 1 dan 4. 


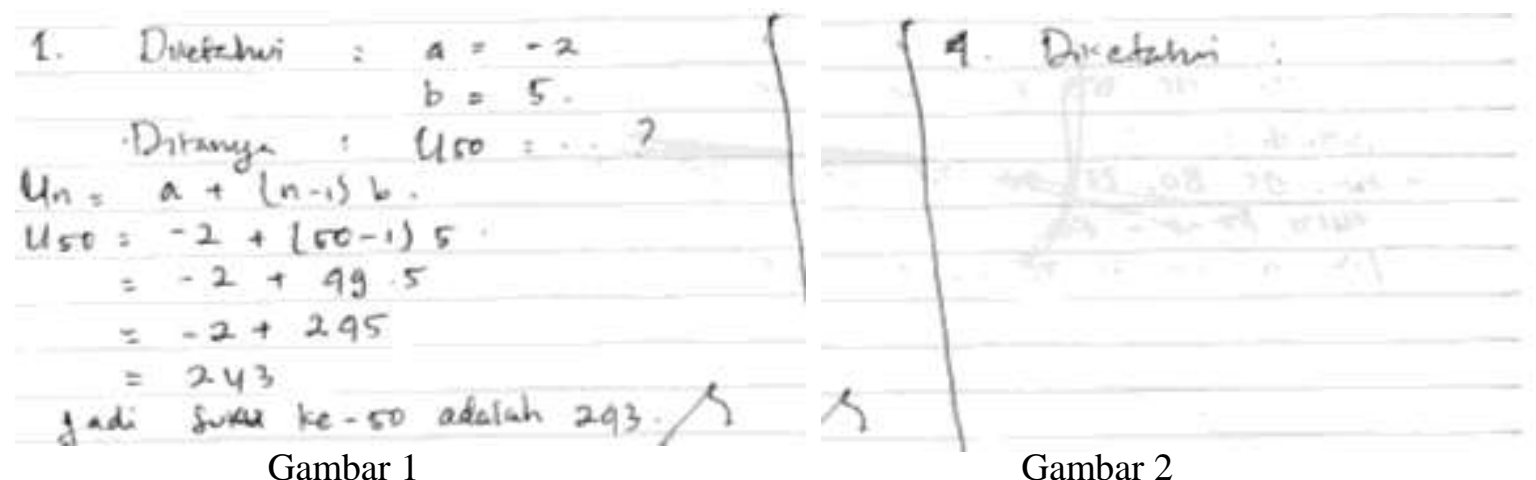

"Informan 2 (SW) sudah mampu mengerjakan semua soal, namun SW masih keliru dalam mengerjakan soal nomor 1 dan nomor 4, karena SW mengerjakannya tidak menggunakan rumus barisan (Un) untuk nomor 1 dan rumus deret untuk nomor 4." Berikut jawaban SW.

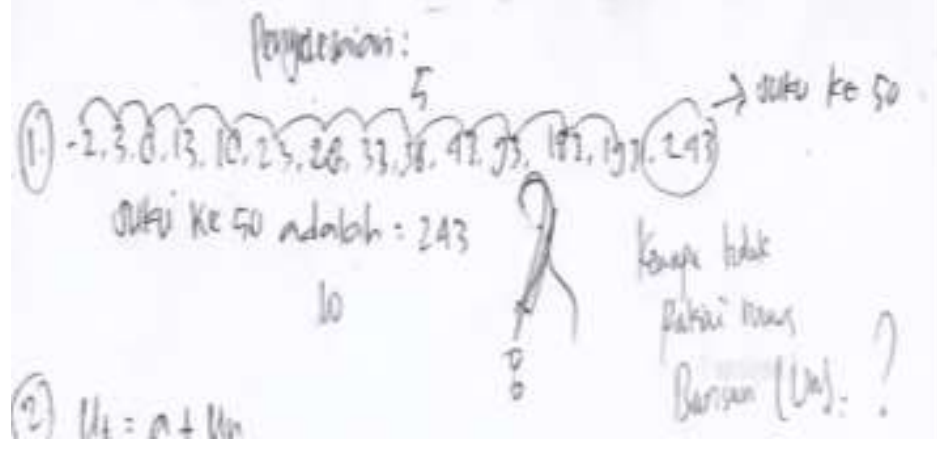

Gambar 3

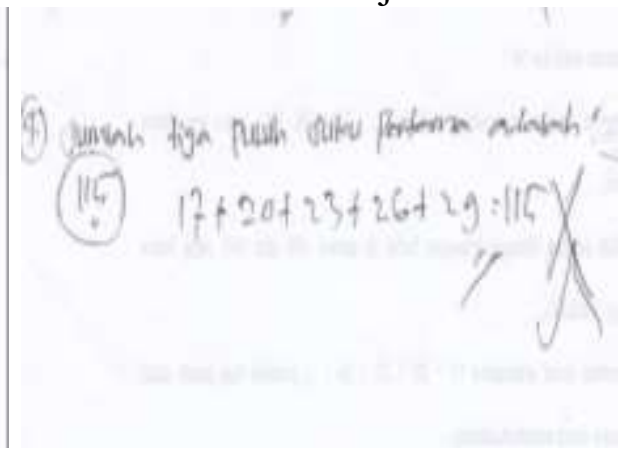

Gambar 4

"Informan $3(\mathrm{CH})$ hanya bisa mengerjakan sampai nomor 3 namun $\mathrm{CH}$ masih keliru di soal nomor 2 dan 3. Selanjutnya $\mathrm{CH}$ belum bisa mengerjakan soal nomor 4 dikerenakan $\mathrm{CH}$ belum mengerti cara mengerjakannya." Berikut jawaban $\mathrm{CH}$ untuk soal nomor 2 dan 3.

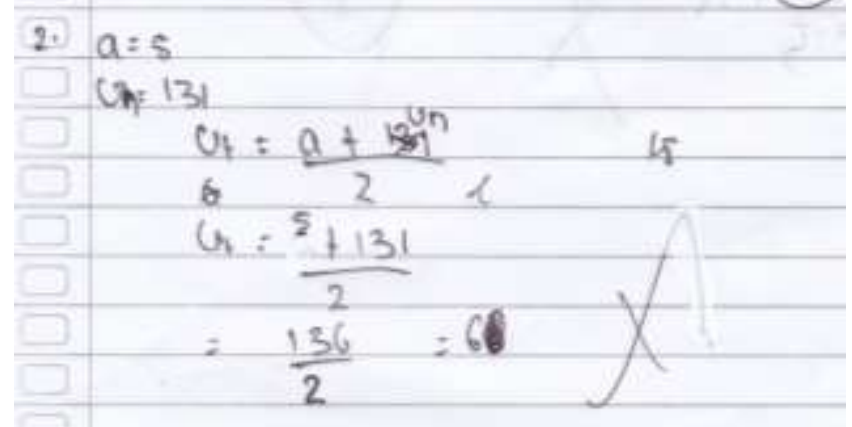

Gambar 5

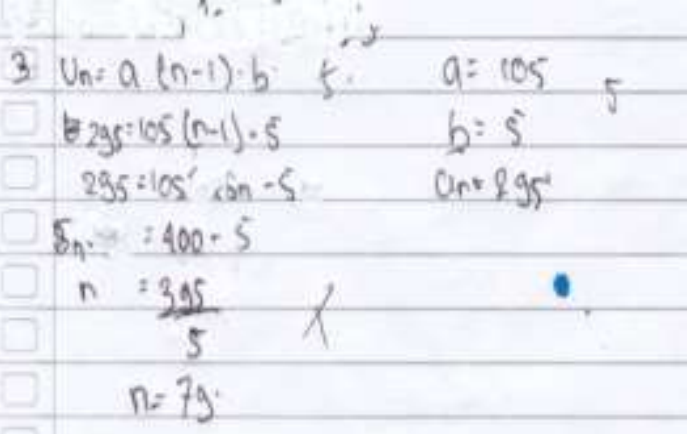

Gambar 6

Tes akhir tindakan siklus II dilaksanakan pada hari sabtu 30 Maret 2019 mulai pukul 09.15 sampai 10.00 dengan alokasi waktu 1 x 45 menit. Terdapat 4 butir soal termuat dalam tes akhir siklus II. Berdasarkan hasil analisis tes akhir tindakan siklus II. Di peroleh informasi bahwa jumlah siswa yang tuntas mengalami kenaikan dari siklus sebelumnya yakni ada 17 yang tuntas dari 20 siswa yang mengikuti tes, dengan nilai persentase ketuntasan belajar klasikal sebesar $85 \%$.

Berdasarkan hasil wawancara peneliti dengan ketiga informan pada siklus II diperoleh informasi sebagai berikut :

"Informan 1 (MS) sudah mampu menyelesaikan semua soal tes akhir tindakan siklus II dengan baik dan benar, misalnya soal nomor 4.” Berikut jawaban MS untuk soal nomor 4. 


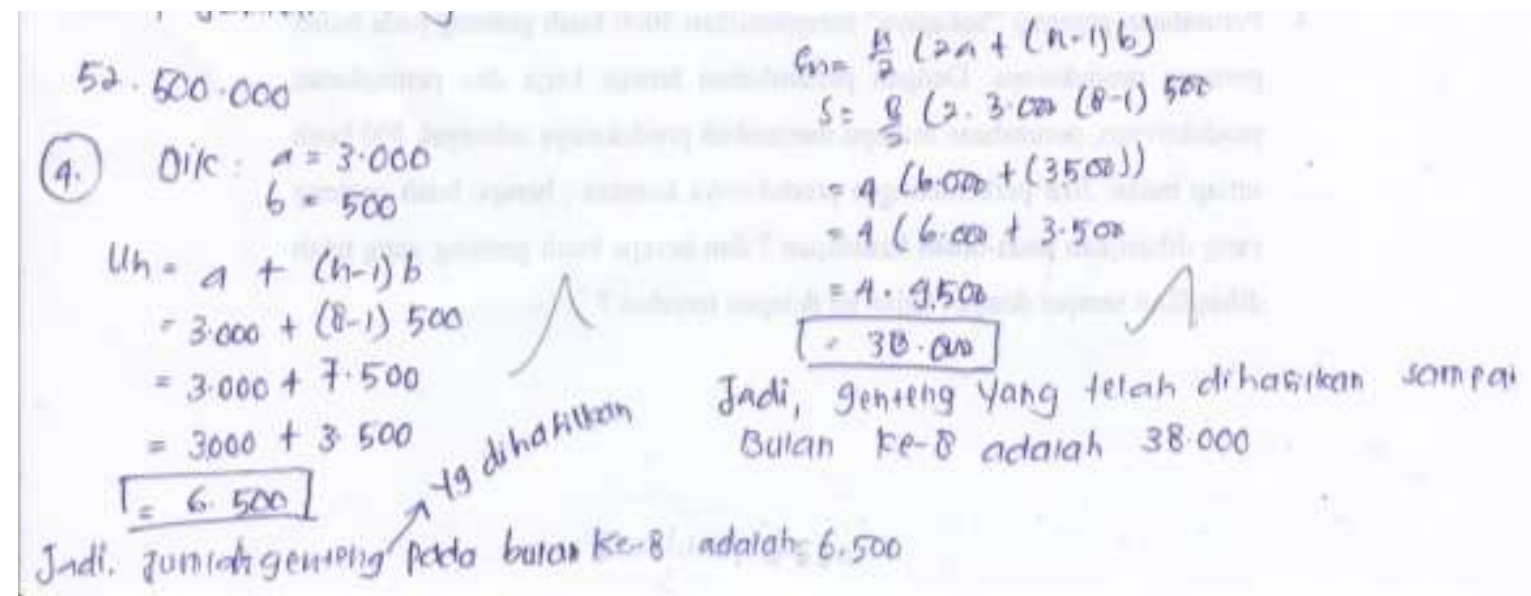

\section{Gambar 7}

"Informan 2 (SW) mampu mengerjakan semua soal, namun SW masih keliru dalam mengerjakan soal nomor 4 bagian deret aritmatika." Berikut jawaban SW untuk nomor 4.

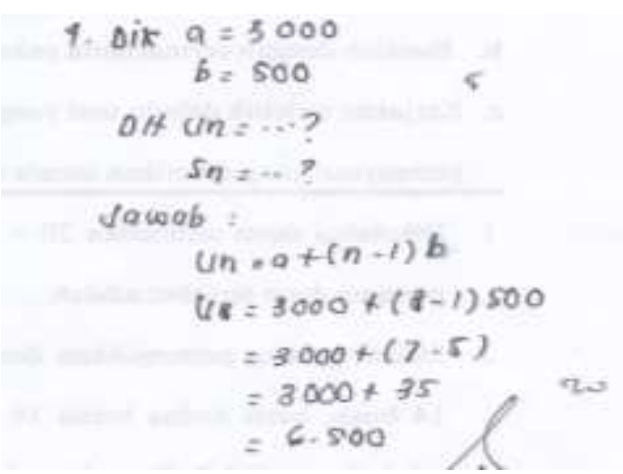

Gambar 8

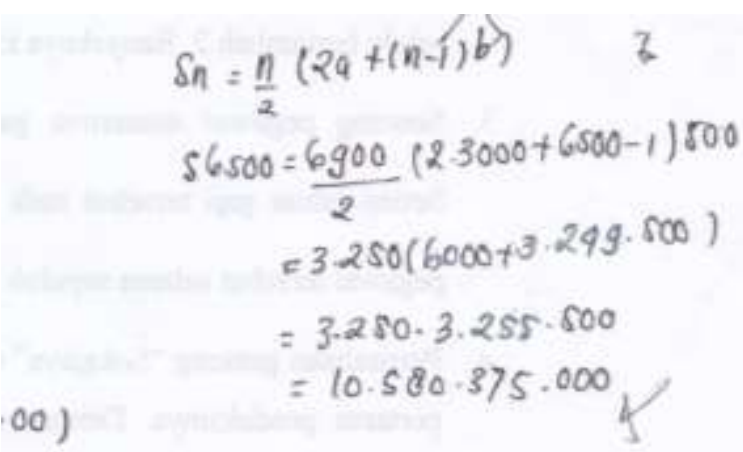

Gambar 9

"Informan $3(\mathrm{CH})$ bisa mengerjakan semua soal namun $\mathrm{CH}$ masih keliru di soal nomor 3 dan nomor 4 bagian deret aritmatika. Sehingga peneliti menganjurkan kepada $\mathrm{CH}$ untuk lebih giat lagi belajar dan mengerjakan soal-soal latihan materi barisan dan deret aritmatika."

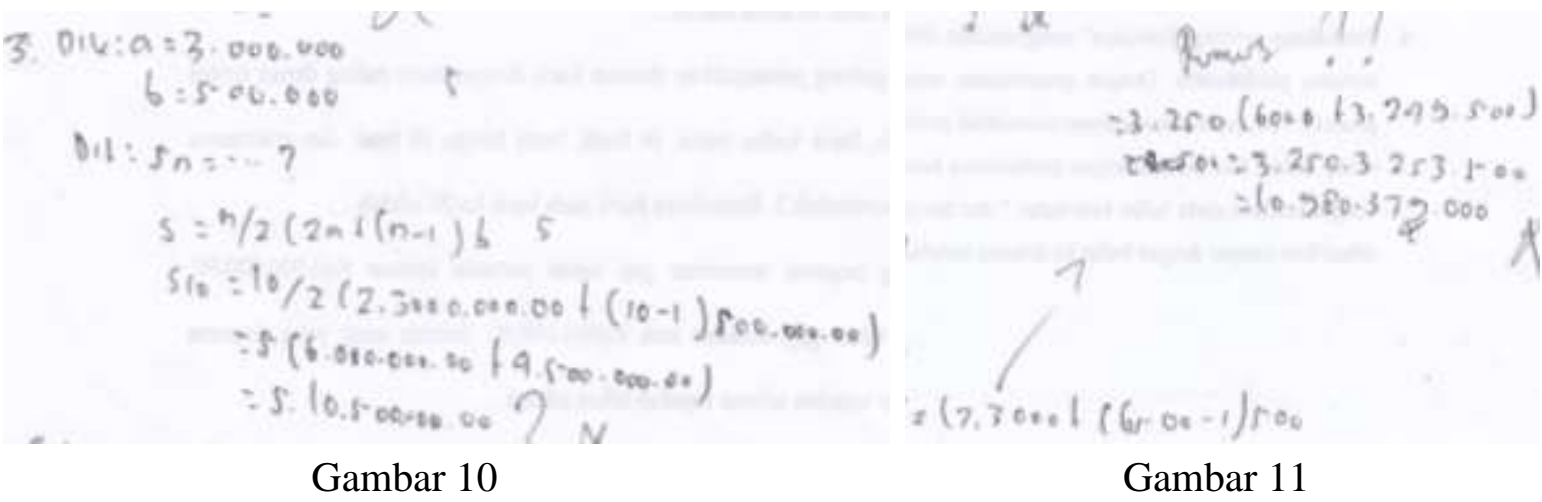

\section{PEMBAHASAN}

Penelitian dilaksanakan pada tanggal 19 Maret 2019 sampai dengan 30 Maret 2019. Penelitian yang dilakukan merupakan penelitian tindakan kelas (PTK) dengan mengacu pada model yang dikembangkan oleh Kemmis dan Mc. Taggart (Arikunto 2017). Penelitian ini terdiri atas dua siklus, setiap siklus terdiri atas 4 komponen yaitu: (1) perencanaan 
(planning), (2) tindakan (acting), (3) pengamatan (observing), (4) refleksi (reflecting). Materi pembelajaran pada siklus I adalah menentukan suku ke-n suatu barisan dan deret aritmatika, sedangkan pada siklus II adalah menentuka suku ke-n secara kontekstual suatu barisan dan deret aritmatika.

Pelaksanaan tindakan dilakukan peneliti dengan menerapkan model pembelajaran kooperatif tipe MURDER. Saat pembelajaran siswa mengkostruksi pengatahuannya dalam memahami konsep barisan dan deret aritmatika, menyelesaikan masalah konteksual berdasarkan bimbingan guru, menjelaskan cara menentukan suku ke-n suatu barisan dan deret aritmatika. Kemudian siswa menerapkan konsep yang diperoleh dalam menyelesaiakan soal barisan dan deret aritmatika yang diberikan guru matematika dalam kehidupan sehari-hari.

Sebelum pelaksanaan tindakan, peneliti memberikan tes awal kepada siswa untuk mengetahui kemampuan siswa pada materi prasyarat. Hal ini sesuai dengan pendapat Sutrisno (2012) yang menyatakan bahwa pelaksanaan tes sebelum perlakuan dilakukan untuk mengetahui pemahaman awal siswa. Adapun materi prasyarat dalam penelitian ini adalah materi barisan dan deret aritmatika, meliputi menentukan pola mencari suku ke-n suatu barisan dan menentukan pola jumlah suku ke-n suatu deret aritmatika. Hasil tes awal dijadikan bahan pertimbangan untuk memilih informan yang akan di ambil hasil pekerjaannya dan paparan hasil wawancara mengenai cara mengerjakan tes akhir tindakan serta digunakan untuk menentukan kelompok belajar pada siklus I dan siklus II.

Pembelajaran pada siklus I dan siklus II dilaksanakan dengan menerapkan model pembelajaran kooperatif tipe MURDER. Penerapan model ini dimaksutkan untuk meningkatkan hasil belajar siswa pada materi barisan dan deret aritmatika. Pada proses pelaksanaan tindakan, langkah-langkah model pembelajaran kooperatif tipe MURDER yaitu: (1) fase mood (menumbuhkan minat belajar siswa), (2) fase understand (pembentukan pemahaman) (3) fase recall (mengulang ide utama) (4) fase detect (menemukan kekeiruan), (5) fase expand (memperluas), (6) fase review (merangkum).

Tahap mood dilakukan guru dengan berusaha menciptakan suasana yang rileks dan memotivasi siswa dengan memberikan informasi dan menunjukan fenomena-fenomena menarik dalam kehidupan sehari-hari yang terkait dengan metri pelajaran serta menjelaskan manfaat yang diperoleh setelah mempelajari materi tersebut. Sehingga sebelum masuk pada pembelajaran inti, siswa sudah terfokus dan ada rasa ingin tahu terhadap materi yang akan dipelajari. Memotivasi siswa sangatlah penting dalam belajar, hal ini sesuai dengan pendapat Kiswoyowati (2011) yang menyatakan bahwa dalam kegiatan belajar, motivasi merupakan faktor yang sangat penting. Motivasi merupakan pengarah untuk kegiatan belajar kepada tujuan yang jelas yang diharapkan dapat tercapai. Jika siswa memiliki motivasi yang kuat, maka siswa tersebut dapat menghasilkan prestasi yang baik dan menjadi contoh buat para siswa yang lain.

Setelah mood siswa bagus, guru membentuk kelompok kecil beranggotakan 4 orang siswa dan membagi anggota kelompok kecil tersebut menjadi dua pasangan dyad, yaitu dyad-1 dan dyad-2 serta memberikan LKPD pada masing-masing kelompok. Hal ini sependapat dengan Yanto (2015) bahwa pembentukan kelompok belajar bertujuan agar siswa bekerja sama, saling membantu, dan memiliki rasa tanggung jawab terhadap keberhasilan kelompok masing-masing.

Trianto (2010) menyatakan bahwa LKPD merupakan panduan siswa yang digunakan untuk melakukan penyelidikan pemecahan masalah. Pada LKPD itu, terdapat sejumlah pertanyaan yang di susun secara sistematis sehingga dapat membantu siswa dalam membuat kesimpulan yang baik dan benar terhadap materi yang diajarkan oleh guru. 
Tahap understand dilakukan guru dengan mengarahkan masing-masing dyad dalam kelompok belajar diberikan kesempatan untuk membentuk pemahaman secara mandiri dengan membaca dan memahami materi secara mendalam. Pada tahap ini siswa tidak hanya berperan sebagai penerima informasi dalam kegiatan pembelajaran, tetapi ikut mengkonstruksi pengetahuannya secara mandiri. Hal ini sependapat dengan Laksana (2009) yang menyatakan bahwa pengalaman langsung juga dapat di peroleh siswa dengan melibatkan mereka secara aktif dalam setiap kegiatan pembelajaran. Peran guru adalah membagi materi dalam LKPD menjadi beberapa bagian sehingga dapat memudahkan siswa dalam membagi tugasnya serta guru mengarahkan siswa untuk mencermati poin-poin penting yang ada pada materi barisan dan deret aritmatika dalam LKPD.

Tahap recall dilakukan guru dengan mengarahkan siswa dalam kelompok untuk membaca, memahami, dan mendiskusikan tugas-tugas yang terdapat pada LKPD. Setelah salah satu anggota dyad-1 menemukan jawaban tugas, anggota lain menulis sambil mengoreksi jika ada kekeliruan. Hal yang sama juga dilakukan oleh pasangan dyad-2. Pada tahap ini, siswa dilatih untuk mengemukakan ide-ide menggunakan kata-kata sendiri mengaitkan konsep-konsep sebelumnya untuk menemukan solusi dari suatu permasalahan. Tugas guru pada saat ini adalah sebagai fasilitator, mengamati aktivitas siswa, membantu jika siswa mengalami kesulitan. Pada tahap ini juga terjadi diskusi antar kelompok sehingga siswa aktiv dalam pembelajaran sehingga meminimalisir siswa yang pasif dalam belajar di dalam kelas.

Tahap detect dilakukan guru dengan mengarahkan setiap kelompok mencermati (mengkaji) penyampaian materi dan hasil penyelesaian dari masalah yang dilakukan pada tahap recall. Jika terdapat ketidakcocokan dan ketidaksesuaian dengan apa yang disampaiakan oleh kelompok penyaji, maka diperlukan koreksi terhadap kesalahan yang muncul dengan mengajukan pertanyaan atau pendapat. Kemudian masing-masing dyad-1 dan dyad-2 saling memperlihatkan hasil pekerjaan, kemudian membandingkannya dan mendiskusikannya. Langkah ini memberikan kesempatan kepada siswa untuk memperbaiki kesalahpahaman dan memperdalam pemahaman siswa. Hal ini sesuai dengan pendapat Pugale (Rahmawati 2013) bahwa perlunya pembiasaan untuk memberikan tanggapan terhadap jawaban yang diberikan orang lain dalam pembelajaran matematika sehingga yang dipelajari siswa menjadi lebih bermakna.

Tahap expand dilakukan guru dengan mengarahkan setiap pasangan dyad dapat memberikan contoh atau aplikasi materi yang dipelajari, mengemukakan pendapat, dan pertanyaan terkait dengan topik yang dibahas serta mengaitkannya dengan kehidupan sehari-hari. Pada tahap ini, siswa juga di beri kesempatan untuk menanggapi dan memberikan sanggahan terkait pertanyaan yang muncul pada tahap detect. Langkah ini memberikan kesempatan kepada siswa untuk mengembangkan pengetahuannya berkaitan dengan kehidupan sehari-hari

Tahap review dilakukan guru dengan membimbing setiap kelompok untuk menyimpulkan konsep yang mereka peroleh melalui kegiatan pembelajaran yang telah dilaksanakan sekaligus mengevaluasi pemahaman siswa setelah semua masalah telah mereka selesaikan secara bersama. Hal ini sejalan dengan pendapat Purnomo (2011) bahwa guru membimbing siswa untuk menarik kesimpulan-kesimpulan sesuai dengan temuan siswa. Hal ini sesuai dengan pendapat Barlian (2013) yang menyatakan bahwa dalam kegiatan penutup, guru bersama-sama dengan siswa membuat rangkuman/kesimpulan pelajaran.

Setelah kegiatan pembelajaran pada siklus I berakhir, peneliti melanjutkan ke siklus II. Namun, sebelum itu peneliti bersama guru melakukan refleksi terhadap seluruh kegiatan 
pembelajaran yang dilakukan pada siklus I. Refleksi ini bertujuan untuk mengetahui kekurangan serta kekeliruan dalam mengerjakan tes yang diberikan oleh guru pada pelaksanaan pembelajaran pada siklus I. Selanjutnya guru dan peneliti bersama-sama mencari solusi agar masalah yang terjadi pada siklus I dapat teratasi pada siklus berikutnya yaitu siklus II. Hal ini sesuai dengan pendapat Arikunto (2017) yang menyatakan bahwa refleksi adalah kegiatan menganalisis data yang telah diperoleh berdasarkan tes awal yang dilakukan sebelum kegiatan pembelajaran berlangsung, hasil tes akhir tindakan, hasil observasi, catatan lapangan, dan wawancara sebagai dasar perbaikan siklus berikutnya.

Pembahasan penerapan model pembelajaran kooperatif tipe MURDER dalam penelitian ini adalah hasil observasi aktivitas guru dan siswa serta hasil catatan lapangan. Berdasarkan hasil observasi aktivitas guru bahwa pencapaian di siklus II meningkat dari siklus I. Adapun skor dari aktivitas guru meningkat dari kategori baik ke sangat baik berdasarkan kriteria yang dibuat yakni diperoleh nilai 18 atau dalam persentase $75 \%$ pada siklus I menjadi 22 atau persentase 91\% siklus II. Begitupula skor yang diperoleh pada aktivitas siswa meningkat dari kategori baik ke sangat baik. Berdasarkan kriteria yang dibuat diperoleh nilai 17 atau dengan persentase 70,8\% pada siklus I menjadi 21 atau dengan persentase $87 \%$ pada siklus II. Pada siklus I , hasil lembar observasi aktivitas guru menunjukkan bahwa guru dapat mengelolah pembelajaran dengan baik, dan lembar hasil observasi aktivitas siswa menunjukkan bahwa siswa dapat mengikuti pembelajaran dengan baik, sedangkan pada siklus II, hasil lembar observasi aktivitas guru menunjukkan bahwa guru dapat mengelolah pembelajaran dengan sangat baik, dan lembar hasil observasi aktivitas siswa menunjukkan bahwa siswa mengikuti pembelajaran dengan sangat baik.

Selanjutnya berdasarkan hasil catatan lapangan diperoleh bahwa pada siklus II, guru dapat mempertahankan kelebihan dan memperbaiki kekurangan yang ada pada siklus I. catatan lapangan pada siklus I memberikan informasi bahwa saat guru mengajar di dalam kelas masih ada siswa yang berada di luar kelas, terdapat dua siswa yang keluar masuk kelas dan dua siswa bermain game dihandpone sehingga suasana kelas agak sedikit ribut pada fase detect, sedangkan pada siklus II, terdapat satu siswa yang keluar masuk kelas dan satu siswa yang bermain game dihandpone pada fase detect.

Berdasarkan tes akhir tindakan pada sikus II terjadinya peningkatan dari siklus I. Hal ini sebanding dengan hasil belajar siswa yang di tinjau dari KBK meningkat dari $71 \%$ di siklus I menjadi $76 \%$ di siklus II.

Dari hasil pekerjaan tes akhir tindakan siklus I dan siklus II terhadap informan diperoleh bahwa informan I (MS) memperoleh nilai 82 pada siklus I meningkat menjadi 100 pada siklus II, informan 2 (SW) memperoleh nilai 70 pada siklus 1 meningkat menjadi 87 pada siklus 2 , informan $3(\mathrm{CH})$ memperoleh nilai 40 pada siklus I meningkat menjadi 62 pada siklus II.

Hasil pekerjaan pada tes akhir tindakan siklus I dan siklus II memberikan informasi bahwa, umumnya siswa dapat menyelesaikan soal barisan dan deret aritmatika dengan cukup baik. Namun, ada beberapa siswa masih kurang teliti dan kurang tangkap dalam mengerjakan tes akhir tindakan dengan langkah-langkah penyelesaian yang telah diajarkan oleh guru matematika kelas X TKJ A SMK Negeri 1 Poso Pesisir Utara sesuai dengan silabus pembelajaran yang ditetapkan dari dinas pendidikan.

Setelah hasil tes akhir tindakan siklus I dan siklus II diperiksa, peneliti melakukan wawancara terhadap informan. Berdasarkan hasil wawancara, memberikan informasi bahwa siswa senang belajar barisan dan deret aritmatika karena ada hubungannya dengan keseharian mereka. Hasil wawancara juga memberikan informasi bahwa pada siklus I siswa kemampuan tinggi dan sedang dapat menerapkan konsep barisan dan deret aritmatika 
walaupun masih agak keliru dalam mengoprasikannya, sedangkan siswa berkemampuan rendah masih melakukan banyak kesalahan namun dapat diminimalisir dengan cara memperbaiki proses belajar siswa melalui pemberian tugas dan motivasi-motivasi tambahan yang akan membuat siswa makin semangat dalam belajar.

Siklus II diperoleh informasi bahwa siswa berkemampuan tinggi dan siswa berkemampuan sedang dapat menerapkan konsep barisan dan deret aritmatika dengan baik dan benar di lihat dari hasil pekerjaan tes akhir siklus II yang mengalami peningkatan dibandingkan siklus I. Sedangkan siswa kemampuan rendah masih kurang teliti dan kurang cepat dalam mengerjakan soal sehingga hasil tes nya tidak mencapai standar ketuntasan yang di tetapkan sekolah namun peneliti menilai bahwa siswa ini sudah bersungguhsungguh dalam belajar.

Berdasarkan hasil penelitian dan pembahasan yang telah dikemukakan di atas, menunjukkan bahwa aktivitas guru dan siswa dalam proses pembelajaran telah mengalami peningkatan dan mencapai indikator keberhasilan tindakan. Hal ini menunjukkan bahwa adanya peningkatan hasil belajar siswa kelas X TKJ A SMK Negeri 1 Poso Pesisir Utara terhadap materi barisan dan deret aritmatika melalui penerapan model pembelajaran kooperatif tipe MURDER.

Sehingga, disimpulkan bahwa penerapan model pembelajaran kooperatif tipe MURDER pada materi barisan dan deret aritmatika dapat meningkatkan hasil belajar siswa kelas X TKJ A SMK Negeri 1 Poso Pesisir Utara dengan mengikuti langkah-langkah yaitu: (1) fase mood (menumbuhkan minat belajar siswa), (2) fase understand (pembentukan pemahaman) (3) fase recall (mengulang ide utama) (4) fase detect (menemukan kekeiruan), (5) fase expand (memperluas), (6) fase review (merangkum materi).

\section{KESIMPULAN}

Berdasarkan hasil analisis data, dapat disimpulkan bahwa penerapan model pembelajaran kooperatif tipe MURDER dapat meningkatkan hasil belajar siswa pada materi barisan dan deret aritmatika di kelas X TKJ A SMK Negeri 1 PPU, dengan menerapkan tahap, yaitu: (1) fase mood (menumbuhkan minat belajar), (2) fase understand (pembentukan pemahaman) (3) fase recall (mengulang ide utama) (4) fase detect (menemukan kekeiruan), (5) fase expand (memperluas), (6) fase review (merangkum).

Kegiatan pada fase mood yakni guru berusaha menciptakan suasana yang rileks serta memotivasi siswa dengan memberikan informasi dan menunjukan fenomenafenomena menarik dalam kehidupan sehari-hari yang terkait dengan meteri pelajaran serta menjelaskan manfaat yang diperoleh setelah mempelajari materi tersebut. Sehingga sebelum masuk pada pembelajaran inti, siswa sudah terfokus dan ada rasa ingin tahu terhadap materi yang akan dipelajari. Setelah mood siswa bagus, guru membentuk kelompok kecil yang beranggotakan 4 orang siswa dan membagi anggota kelompok kecil tersebut menjadi dua pasangan dyad, yaitu dyad-1 dan dyad-2 serta memberikan lembar kerja peserta didik (LKPD) kepada masing-masing kelompok.

Kegiatan pada fase understand yakni masing-masing dyad dalam kelompok belajar diberikan kesempatan untuk membentuk pemahaman secara mandiri dengan membaca dan memahami materi secara mendalam. Pada tahap ini siswa tidak hanya berperan sebagai penerima informasi dalam kegiatan pembelajaran, tetapi siswa akan ikut mengkonstruksi pengetahuannya secara mandiri. Peran guru adalah membagi materi menjadi beberapa bagian sehingga dapat memudahkan siswa dalam membagi tugasnya serta mengarahkan siswa untuk mencermati poin-poin penting dalam materi yang di baca. Guru menggunakan 
lembar kerja peserta didik (LKPD) untuk menunjang proses belajar mengajar di dalam kelas.

Kegiatan pada fase recall yakni didalam kelompok akan timbul interaksi yang efektif antar pasangan dyad melalui kegiatan membaca, memahami, dan mendiskusikan tugas-tugas yang terdapat pada LKPD. Setelah salah satu anggota dyad-1 menemukan jawaban tugas, anggota lain menulis sambil mengoreksi jika ada kekeliruan. Hal yang sama juga dilakukan oleh pasangan dyad-2. Pada tahap ini, siswa dilatih untuk mengemukakan ide-ide menggunakan kata-kata sendiri mengaitkan konsep-konsep sebelumnya untuk menemukan solusi dari suatu permasalahan. Tugas guru pada saat ini adalah sebagai fasilitator, mengamati aktivitas siswa, membantu jika siswa mengalami kesulitan. Pada tahap ini juga terjadi diskusi antar kelompok.

Kegiatan pada fase detect yakni setiap kelompok mengkaji penyampaian materi dan hasil penyelesaian dari masalah yang dilakukan pada tahap recall. Jika terdapat ketidakcocokan dan ketidaksesuaian dengan apa yang disampaiakan oleh kelompok penyaji, maka diperlukan koreksi terhadap kesalahan yang muncul dengan mengajukan pertanyaan atau pendapat. Kemudian masing-masing dyad-1 dan dyad-2 saling memperlihatkan hasil pekerjaan, kemudian siswa membandingkannya.

Kegiatan pada fase expand yakni setiap pasangan dyad dapat memberikan contoh atau aplikasi materi yang dipelajari, mengemukakan pendapat, dan pertanyaan terkait dengan topik yang dibahas serta mengaitkannya dengan kehidupan sehari-hari. Pada tahap ini, siswa juga diberi kesempatan untuk menanggapi dan memberikan sanggahan terkait pertanyaan yang muncul pada tahap detect. Langkah ini memberikan kesempatan kepada siswa untuk mengembangkan pengetahuan yang erat kaitannya dengan kehidupan mereka.

Kegiatan pada fase review yakni guru membimbing setiap kelompok untuk menyimpulkan konsep yang mereka peroleh melalui kegiatan pembelajaran yang telah dilaksanakan di dalam kelas sekaligus mengevaluasi pemahaman siswa setelah semua masalah telah mereka selesaikan secara bersama.

\section{SARAN}

Berdasarkan kesimpulan yang telah dikemukakan di atas, adapun saran yang dapat diberikan oleh peneliti yakni:

1) Pembelajaran matematika dengan menerapkan model pembelajaran kooperatif tipe MURDER, dapat dijadikan alternatif bagi para guru dalam meningkatkan hasil belajar siswa dengan mempersiapakan secara matang segala sesuatu yang dibutuhkan dalam proses pembelajaran, termasuk kesiapan guru dalam mengelolah suasana kelas dan bisa pemanfaatan waktu mengajar yang tersedia dengan baik.

2) Bagi peneliti berikutnya agar dapat mencoba menerapkan model pembelajaran kooperatif tipe MURDER pada materi lain, serta memperhatikan pengaturan waktu dan kelas agar barjalan sesuai rencana dan tujuan pembelajaran.

\section{DAFTAR PUSTAKA}

Arikunto, S., Suhardjono. dan Supardi. (2017). Penelitian Tindakan Kelas. Jakarta: PT Bumi Aksara.

Barlian, I. 2013.Begitu Pentingkah Strategi Belajar Mengajar Bagi Guru?.Jurnal Forum Sosial. [Online]. Tersedia: http: // eprints. Unsri. ac. id/ 2268/2/isi. Pdf [10 April 2019]. 
Kiswoyowati, A. (2011). Pengaruh Motivasi Belajar dan Kegiatan Belajar Siswa Terhadap Kecakapan Hidup Siswa [Online]. Portal Jurnal Universitas Pendidikan Indonesia. 2, (1), 120-126. Tersedia: http://jurnal.upi.edu/file/11-Amin_Kiswoyowati.pdf [3 April 2019].

Laksana, K.S. 2009. Perbedaan Hasil Belajar Fisika antara Model Pembelajaran TANDUR dengan Model Pembelajaran Konvensional pada Siswa Kelas VIII SMP Negeri 4 Palu.Skripsi FKIP UNTAD. Palu: tidak diterbitkan.

Miles, M. B, Huberman, A. M, dan Saldana, J. (2014). Qualitative Data Analysis A Methods Sourcebook, Edition 3. USA : Sage Publications.

Permendiknas Nomor 20 Tahun 2007 tentang Standar Proses Untuk Satuan Pendidikan Dasar dan Menengah.

Permendikbud Nomor 104 Tahun 2014 tentang Penilaian Hasil Belajar Oleh Pendidik Pada Pendidikan Dasar dan Pendidikan Menengah.

Purnomo, Y. W. 2011. Keefektifan Model Penemuan Terbimbing dan Cooperative Learning pada Pembelajaran Matematika. Jurnal 5Pendidikan. [Online]. Tersedia:http//journal.uny.ac.id/ index.php. jk. article. download/ 503/366. [11 April 2019].

Rahmawati,F. 2013. Pengaruh Pendekatan Pendidikan Realistik Matematis Siswa Sekolah Dasar. Journal FMIPA Unila. [Online]. Tersedia: Http:// journal. fmipa.unila.ac.id.index.php / semirat/ article/ view/ 882/701. [1 April 2018].

Santyasa, I. W. (2008). "Pembelajaran Inovatif, Model Kolaboratif, Berbasis Proyek, dan Orientasi NOS”. Makalah disajikan dalam Seminar di Sekolah Menengah Atas (SMA) Negeri 2 Semarapura: Jurusan FPMIPA Universitras Pendidikan Ganesha.

Trianto. 2010. Mendesain Model Pembelajaran Inovatif-Progresif. Jakarta: Kencana Pradana Media Grup.

Yanto. 2015. Penerapan Mode Pembelajaran MURDER di Kelas VIII D SMPN 7 Palu.Skripsi FKIP Universitas Tadulako. Palu : Tidak diterbitkan.

Yuniartim, Sudarman, dan Maxinus. (2017). Penerapan Model Pembelajaran Perseorangan dan Kelompok Kecil (Ppkk) untuk Meningkatkan Hasil Belajar Siswa dalam Menyelesaikan Soal Penjumlahan dan Pengurangan Pecahan di Kelas Vii B7 Smp Negeri 14 Palu [online]. Aksioma Jurnal Pendidikan Matematika. 6, (1), 101. Tersedia : http://jurnal.untad.ac.id/jurnal/index.php/AKSIOMA/article/view/8372 [2 Juli 2019] 